\title{
COMPENSATION AND MOTIVATION EFFECT TO EMPLOYEES' JOB SATISFACTION
}

\author{
Rasmi, Amiruddin, Sumardi \\ Hasanuddin University, Makassar Indonesia
}

\begin{abstract}
The research aims to determine effect of compensation and motivation on employees' job satisfaction. Compensation is something that employees' receive as a substitute for the contribution of their services to company. Compensation is one of human resource management function of which deals with all kinds of individual award giving as exchange in performing organizational tasks. Motivation can simply be defined as a condition or action that encourages a person to do a job or activity as much as possible. People with low motivation tend to display feelings of discomfort and displeasure with their work. Job satisfaction is basically something that is individual feel. Each individual has a different level of satisfaction in accordance with the value system that applies to him. The higher the assessment of the perceived activity in accordance with the wishes of the individual, the higher his satisfaction with the activity will be.

Method used in this research is mixed method of both quantitative and qualitative.

This research yields findings about the significance of financial and non-financial compensation effect through motivation towards employees' job satisfaction
\end{abstract}

Keywords : Compensation, Motivation, Work Satisfaction.

\section{Introduction}

In business world both industry and services has required reliable human resources that can manage it, because human resources are the main actors who perform operations of the overall organizational activities, ranging

*Corresponding author's email: a.amiruddin@fe.unhas.ac.id ISSN: 2549-3221 (Print) 2549-323X (Online)

DOI: $10.26487 /$ hebr.v\%vi\%i.1188 from planning to evaluation with the existence of other resource relationships supporting one another.

However, we have to keep in mind that human resources themselves as one factor of production, like other production factors, its input is processed 
by the company and will produce output. The existence of human resources (HR) is very important in the company, because human resources support the company through work, talent, creativity, encouragement and real role as it can be witnessed in every company or in organization.

Without human element in the company, it is unlikely that the company can move towards the desired goals. Thus HR should be ready, willing and able to contribute to the business achievement and organizational goals. Therefore, every company is in need of employees' who can complete the work given to him. The results of their work will show level satisfaction that they felt.

Therefore, provision of compensation is very important to support employees" job satisfaction in order to improve their productivity. Compensation sometimes results in social jealousy among employees', if the compensation is unfair and unfavorable, which will lead to a decrease in the level of employment of employees' who feel unfair in giving to employees' performance (RA Ritawati, 2015).

Compensation is something that employees' receive in lieu of their service contribution to the company. Compensation is one of execution of human resource management function which relates to all kinds of individual award giving as exchange in performing organizational duties. Compensation is a major expense of expertise or work and loyalty in the company business of 21st century. Compensation is the main reason why most people look for work (Rivai, 2004: 357). Compensation also increases employees' motivation for performance measures, thus helping employees' allocate employees' time and effort. Compensation is one way organizations to improve job performance, motivation, and job satisfaction of employees'
(Rachmawati, 2008: 144)

Motivation can simply be defined as a condition or action that encourages a person to do a job or activity as much as possible to do and produce. A person with low motivation tends to display feelings of discomfort and displeasure with his work. So the greater the motivation of the individual as employees' can improve the performance of the employees' themselves. So motivation becomes an important thing for employees', motivated employees' will feel happier, healthier and always want to come to work (Rivai, 2004: 456).

Each company must also always pay attention to employees' job satisfaction, including companies engaged in services. Job satisfaction is basically something that is individual. Each individual has a different level of satisfaction in accordance with the value system that applies to him. The higher the assessment of the perceived activity in accordance with the wishes of the individual, the higher his satisfaction with the activity will be. Thus satisfaction is an evaluation that describes a person for feeling his attitude happy or displeased, satisfied or not satisfied in work (Rivai, 2004).

\section{Formulation of the problem}

Based on the introduction that has been mentioned previously, and then the main problem in the research is the effect of compensation on employees' job satisfaction. Furthermore, another problem to be analyzed is the influence of motivation on the level of employees' job satisfaction. With the problems outlined above, here are the research questions we want to answer in this research:

1. How is the influence of compensation and motivation either direct or indirect influence on employees' job satisfaction of PT. Bank Rakyat Indonesia, Tbk Makassar city? 
2. Is the influence of compensation or motivation more dominant positive and significant impact on employees' work satisfaction PT. Bank Rakyat Indonesia, Tbk Makassar city?

Referring to the above theoretical basis and the results of previous research, we can be arranged research framework, for more details frame of mind can be seen in the following figure:

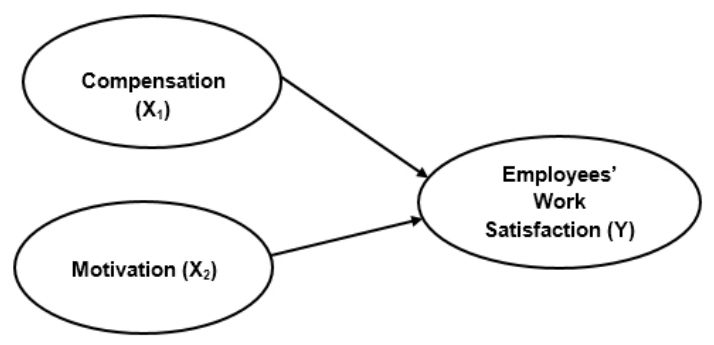

Figure 1. Research Framework

\section{Hypothesis}

Referring to the article introduction, the formulation of the problem and the frame of mind that has been stated above, the authors propose the research hypothesis as follows:

1. It is alleged that both financial and nonfinancial compensation directly and indirectly have a positive and significant effect through motivation on employees" work satisfaction at PT. Bank Rakyat Indonesia Tbk, Makassar city.

2. Compensation is considered the most dominant variable in influencing employees" work satisfaction at PT. Bank Rakyat Indonesia Tbk, Makassar City.

\section{Research Site and Objects}

In the preparation of this study, the authors conducted research on PT. Bank Rakyat Indonesia (Persero) Tbk Makassar Area located at Jalan Achmad
Yani No.8 Makassar, South Sulawesi. The reason of choosing the object of research in place with the consideration that the author can obtain data easily, consider the time to be used, and cost efficient.

\section{Population and Sample}

This research is conducted by taking data from respondents. The data taken are from samples representing the entire population. Then the samples taken must represent the population in the study. The population is employees' of PT. Bank Rakyat Indonesia, Tbk Makassar City with the total population is 112 employees'. The sample in this study is a portion of the population taken, as a data source representing the entire population. The sample in this study is 52 employees'. To determine the samples number used were done by determining using the Slovin formula.

\section{Data Analysis, Results and Discussion}

The method of analysis used to analyze the data obtained to test the hypothesis that has been proposed in this study using statistical tests (F Test and $t$ Test).

This study examines the hypotheses about the effect of compensation and motivation on employees'job satisfaction. The following is an explanation of the results of the data and analysis.

\section{F Test (Simultaneous Test)}

$\mathrm{F}$ test or simultaneous test is a test of significant influence of compensation and motivation variables on job satisfaction. Based on the results of data processing obtained $\mathrm{F}_{\text {count }}$ of 104.836 while the $\mathrm{F}_{\text {table }}$ of 3.19. This means $F_{\text {count }}>F_{\text {table }}$ (104.836> 3.19) is significant. So from the variable compensation and motivation has a positive and significant effect on the variable of job satisfaction. 
Based on results of research data analysis shows that the results of the $\mathrm{F}_{\text {count }}$ that is equal to 104.836 and $\mathrm{F}_{\text {table }}$ of 3.19 then it can be said there is influence between variable $\mathrm{X} 1$ and $\mathrm{X} 2$ to variable $\mathrm{Y}$, this indicates that the change in rising or decreasing of variable on compensation and motivation have an effect on job satisfaction of employees'.

\section{T Test (Partial Test)}

The $t$ test result of compensation and motivation obtained the sig value of 0.05 and $t_{\text {count is }}$ bigger than $t_{\text {table }}\left(t_{\text {count }}>t_{\text {table }}\right)$, so the hypothesis states that compensation and motivation have a positive effect on employees' job satisfaction. Therefore, to examine whether each variable has effect on job satisfaction to employees' a t test (partial test) with a confidence level of $95 \%$ is used.

\section{Hypothesis Test on the Effect of Compensation on Employees' Job Satisfaction}

The first hypothesis test in this study (H1) states that compensation has a positive and significant effect on employees' job satisfaction.

$\mathrm{H}_{\mathrm{o}}=$ Compensation does not have positive and significant effect on employees' job satisfaction.

$\mathrm{H}_{1}=$ Compensation does have positive and significant effect on employees' job satisfaction.

Based on the results of the data then obtained the value for $t_{\text {count }}$ variable compensation of 5.655, while $t_{\text {table }}$ of 0.2732 (df - $2-1=49$ ). In addition the significance value is 0.000 smaller than the significance level $(\alpha) 0.05$, because the value of $t_{\text {count }}>t_{\text {table }}(5.655>0.2732)$ and the significance value smaller than the significance level (a) 0.05 (0.000 $<0.05$ ), then $\mathrm{Ho}$ is rejected and $\mathrm{H} 1$ accepted, it means that the compensation has a positive and significant effect on employees' job satisfaction.

Based on the results of t-test, it is known that the compensation variable has a significant influence on employees' work satisfaction at PT. Bank Rakyat Indonesia Tbk Makassar. The effect of compensation shows that the value of coefficient of compensation variable is $53.6 \%(0.536)$ with a positive direction, because compensation or reward system is seen as a form of reward to the employees' for their services or contribution to the organization which is reflected from their achievement in work.

\section{Hypothesis Testing Influence Motivation on Employees' Job Satisfaction}

The first hypothesis test in this study (H2) states that motivation has a positive and significant effect on employees' job satisfaction.

$\mathrm{H}_{\mathrm{o}}=$ Motivation does not have positive and significant effect on employees' job satisfaction

$\mathrm{H}_{2}=$ Motivation does have positive and significant effect on employees' job satisfaction

The test results show the value for $t_{\text {count }}$ motivation of 3.061 while $t_{\text {table }}$ of 0.2732 ( $\mathrm{df}-2-1=49)$. In addition the significance value is 0.004 less than the significance level ( $\alpha$ ) 0.05, since the value of $t_{\text {count }}>$ $t_{\text {table }}(3.061>0.2732)$ and the significance value is smaller than the significance level (a) 0.05 (0.004<0, 05), then Ho is rejected and $\mathrm{H} 2$ accepted, meaning motivation has a positive and significant effect on employees' job satisfaction.

Based on the results of $t$ test, it is known that the motivation variable has a significant effect on employees' work satisfaction PT. Bank Rakyat Indonesia Tbk, Makassar city. The result of the influence of motivation shows that the coefficient value of compensation 
variable is $16.4 \%(0.164)$ with a positive direction. This means that the better the motivation the higher employees' job satisfaction will be.

Based on the explanation of the above research results it can be concluded that the compensation is a positive and significant effect on employees' work satisfaction PT. Bank Rakyat Indonesia Makassar city, as well as the motivation has a positive and significant impact on employees' job satisfaction PT. Bank Rakyat Indonesia Makassar. Compensation variables are more dominant than motivation, however, with different significance values indicated by each variable, i.e. $0.000(0,000<0.05)$, while the motivation is $(0.004<0.05)$.

The most dominant effect on employees' job satisfaction is compensation, this can be seen on the value of $\mathrm{F}_{\text {count }}>\mathrm{F}_{\text {table }}(104.836>3.19)$, and the significance value is smaller than the level of significance ( $\alpha$ ) 0.05 (0.000 $<0.05)$.

\section{Conclusion}

From the analysis and discussion that has been described and explained previously, the researchers draw some conclusions on the results of the analysis that the compensation and motivation have a positive and significant impact on employees' job satisfaction and the most dominant variable affecting employees' job satisfaction is compensation.

\section{Suggestion}

From the conclusion that has been put forward, the researcher gives some suggestions as consideration for PT. Bank Rakyat Indonesia Tbk, Makassar city as follows: it is recommended PT. Bank Rakyat Indonesia Makassar is not only a compensation system that is noticed but also needs to be considered is to maintain employees' motivation while working. In order to improve employees' motivation and stay well maintained PT. Bank Rakyat Indonesia Makassar provides good training with good quality.

To maintain employees' motivation, PT. Bank Rakyat Indonesia should have a good compensation system applicable according to the existing PT. Bank Rakyat Indonesia (Persero) Tbk, both financial compensation and nonfinancial compensation.

\section{REFERENCES}

Asrianti. 2012. Pengaruh Kompensasi Finansial dan Nonfinansial Terhadap Kinerja Karyawan PT. BankRakyatIndonesia(PERSERO) Tbk. Wilayah Makassar. Skripsi tidak diterbitkan. Makassar: Fakultas Ekonomi dan Bisnis Unversitas Hasanuddin.

Dessler Gary. 1997. Manajemen Sumber Daya Manusia Human Resource Management 7e. Jilid 2. Jakarta : Prehallindo.

Dharmala Hadi Saputra. 2014. Pengaruh Kompensasi dan Motivasi Terhadap Kepuasan Kerja dan Kinerja Karyawan Pada Perusahaan Daerah Air Minum (PDAM) Kabupaten Lumajang. (Online). (https://scholar.google. co.id/). Diakses Rabu 18 Mei 2016 pukul 23.15 WITA

Edy Sutrisno. 2011. Manajemen Sumber Daya Manusia, edisi Pertama Cetakan ke-3. Jakarta: Prenada Media Group.

Faustino. 2003. Manajemen Sumber Daya Manusia. Yogyakarta : C.V Andi Offset.

Hasibuan Malayu. 2002. Manajemen Sumber Daya Manusia, edisi revisi. Jakarta: PT. Bumi Akasara.

Ikmal Nur Muflih. 2015. Pengaruh Kompensasi dan Motivasi Kerja 
Terhadap Kepuasan Kerja Karyawan PT. Aseli Dagadu Djogja. (Online). (https://scholar. google.co.id/). Diakses Kamis 19 Mei 2016 pukul 11.57 WITA

Jurnal Manajemen Dan Bisnis Indonesia. 2015. Pengaruh Kompensasi dan Motivasi Terhadap Kepuasan Kerja Karyawan. Vol. 1 No. 2. Diakses Rabu 23 Mei 2016 pukul 05.30 WITA.

Mangkuprawira. 2004. Manajemen Sumber Daya Manusia Strategik. Jakarta Selatan: Ghalia Indonesia. Mondy. 2008. Manajemen Sumber Daya Manusia. Jakarta: Erlangga.

Moh. Susetyon Nugroho dkk. 2014. Pengaruh Kompensasi dan Motivasi Terhadap Kepuasan Kerja dan Kinerja Karyawan Pada Bojana Tour Blitar. (Online). (https://scholar.google.co.id/). Diakses Kamis 19 Mei 2016 pukul 13.04 WITA

Ngurah Bagus Dhermawan dkk. 2012. Pengaruh Motivasi, Lingkungan Kerja, Kompetensi, Dan Kompensasi Terhadap Kepuasan Kerja Dan Kinerja Pegawai Di Lingkungan Kantor Dinas Pekerjaan Umum Provinsi Bali. Jurnal Manajemen Vol. 6 No. 2. diakses 18 Mei 2016 pukul 22.12 WITA

Rachmawati. 2008. Manajemen Sumber Daya Manusia. Yogyakarta : ANDI

Ritawati RA. 2015. Peranan Kompensasi Terhadap Peningkatan Kinerja Karyawan pada Perbankan Syariah Palembang. I Finance Volume 1(1)

Rivai. 2004. Manajemen Sumber Daya Manusia untuk Perusahaan Dari Teori ke Praktik. Jakarta: PT. Raja Grafindo Persada.

Satori dan Komariah,A. 2011. Metode Penelitian Kualitatif. Bandung: Alfabeta.
Sarwono. 2011. Mengenal path analysis. Jurnal Ilmiah Manajemen Bisnis Volume 1(2): 285-296

Sunyoto Danang. 2012. Manajemen Sumber Daya Manusia, cetakan pertama. Jakarta Penerbit CAPS (Center for Academic Publishing Service).

Suwanto dan Donni. 2011. Manajemen Sumber Daya Manusia dalam Organisasi Publik dan Bisnis, cetakan pertama. Bandung: CV. Alfabeta

Sugiyono. 2010. Metode Penelitian Kuantitatif dan Kualitatif Dan $R$ \& $D$. Bandung: Alfabeta.

Yusron Rozzaid dkk. 2015. Pengaruh Kompensasi Dan Motivasi Terhadap Kepuasan Kerja Karyawan (Studi Kasus Pada PT. Nusapro Telemedia Persada Cabang Banyuwangi). Jurnal Manajemen Dan Bisnis Indonesia Vol. 1 No 2. Diakses Selasa 17 Mei 2016 Pukul 17.14 WITA. 